\title{
KAJIAN MUTU IKAN TONGKOL (Euthynnus affinis) SEGAR DI PASAR BAHU MANADO
}

\author{
Agustina E. Manggaprouw, Roike I. Montolalu dan I Ketut Suwetja
}

Fakultas Perikanan dan Ilmu Kelautan, Universitas Sam Ratulangi, Manado, Sulawesi Utara.

\begin{abstract}
ABSTRAK
Penelitian ini bertujuan mempelajari tingkat kesegaran ikan Tongkol yang dijual di pasar Bahu. Perlakuan dalam penelitian ini adalah sebagai berikut : Waktu pengambilan sampel yang terdiri atas: jam $06.00-07.00,11.00-12.00$ dan $16.00-17.00$, serta pedagang yang terdiri atas: pedagang 1 , pedagang 2 dan pedagang 3. Ulangan dalam penelitian ini adalah 3 kali pengambilan sampel yaitu hari pertama, hari kedua, dan hari ketiga. Penelitian ini menggunakan metode deskriptif, data dianalisis menggunakan Microsoft excel sebagai rerata 3 variabel independen dengan standar deviasi (SD).

Hasil penelitian diperoleh nilai rata-rata TVB-N ikan Tongkol (Euthynnus affinis) yang terendah adalah $(11,2 \mathrm{mg} \mathrm{N} / 100 \mathrm{gr}$ sampel) pada pengambilan ikan Tongkol jam 06.00-07.00 sedangkan nilai rerata $(14 \mathrm{mg}-\mathrm{N} / 100 \mathrm{~g}$ sampel). Nilai rerata terendah pada pengambilan ikan Tongkol pada jam 12.00-13.00 adalah (11,2 mg N/100 gr sampel) sedangkan nilai rerata TVB-N yang tertinggi adalah (14 $\mathrm{mg}-\mathrm{N} / 100 \mathrm{~g}$ sampel). Nilai rerata TVB-N yang terendah pada jam 16.00-17.00 (22,4 mg N/100 gr sampel) sedangkan nilai rerata yang tertinggi adalah (28 mg N/100 gr sampel). Nilai rerata $\mathrm{pH}$ pada jam $06.00-07.00$, nilai rerata terendah pada pedagang 2 dan 3 nilainya sama 5,4 sedangkan nilai tertinggi ditemukan pada pedagang 1 adalah 5,43. Nilai rerata $\mathrm{pH}$ terendah pada pengambilan ikan tongkol pada jam 12.00-13.00 ditemukan pada pedagang 2 dan 3 nilainya sama 5,46 sedangkan nilai tertinggi ditemukan pada pedagang 1 adalah 5,53. Nilai rata-rata $\mathrm{pH}$ terendah pada pengambilan ikan tongkol pada jam 16.00-17.00 ditemukan pada pedagang 1 adalah 5,53 sedangkan nilai tertinggi ditemukan pada pedagang 2 dan 3 nilainya sama 5,56. Nilai organoleptik yaitu mata, insang, lendir permukaan badan, daging (warna dan kenampakan) dan tekstur terdapat korelasi positif yaitu nilai tertinggi pada ketiga pedagang terdapat pada pengambilan sampel pagi hari, selanjutnya menurun pada pengambilan sampel siang hari dan sore hari, walaupun demikian nilai organoleptik ini masih masuk kategori ikan bermutu segar dan agak segar yaitu $>6$.
\end{abstract}

Kata kunci: Ikan Tongkol (Euthynnus affinis), kajian mutu, pH, TVB-N, organoleptik.

\section{PENDAHULUAN}

Ikan merupakan komoditi yang cepat busuk, sehingga penanganan ikan Tongkol (Euthynnus affinis) segar merupakan salah satu bagian penting dari mata rantai industri perikanan karena dapat mempengaruhi mutu ikan sebagai bahan mentah untuk proses lebih lanjut (Afrianto dan Liviawaty, 1989). Mempertahankan mutu ikan sebaik dan selama mungkin, dapat dilakukan dengan cara menghambat atau menghentikan kegiatan enzim dan mikro organisme yang terdapat pada tubuh ikan dan menghindari terjadinya kontaminasi. Mutu ikan adalah nilai-nilai tertentu yang diinginkan pada suatu produk. Mutu ikan antara lain ditentukan oleh komposisi kimia dari ikan, Total Volatile Bases Nitrogen (TVB-N) dan nilai organoleptik (Seokarno, 1985). Penentuan kadar TVB-N merupakan metode uji kesegaran bakteriologis atau metode pengukuran hasil uji bakterial pada saat ikan mati setelah hampir melewati fase rigor mortis akan memasuki fase autolysis dimana proses kerja enzim pada tubuh ikan lebih aktif dalam merombak senyawasenyawa yang kompleks menjadi senyawasenyawa sederhana (Suwetja, 2006).

Ikan Tongkol adalah salah satu jenis ikan yang dijual di Pasar Bahu, ikan ini digemari karena mempuyai rasa yang enak, selain itu harganya juga dapat dijangkau oleh masyarakat. Seperti ikan segar lainnya, ikan tongkol juga mudah mengalami penurunan mutu yang mengarah kepada pembusukan, sehingga harus dilakukan penanganan yang baik selama berada dalam rantai pemasaran sampai ke tangan konsumen. Oleh karena itu, perlu dilakukan penelitian tentang kajian mutu ikan Tongkol yang diambil pada waktu dan pedagang yang berbeda di pasar Bahu. Adapun tujuan dari penelitian ini adalah mengkaji/mempelajari tingkat kesegaran ikan Tongkol yang dijual di pasar Bahu dengan waktu pengambilan sampel dan pedagang yang berbeda. 


\section{METODOLOGI PENELITIAN}

Bahan baku yang digunakan dalam penelitian ini adalah ikan Tongkol (Euthynnus affinis), dengan ukuran umumnya $30-40 \mathrm{~cm}$, sedangkan berat $1,720 \mathrm{~kg}$. Bahan-bahan kimia adalah es batu, Trichloro Acetic Acid (TCA) $7,5 \%, \mathrm{~K}_{2} \mathrm{CO}_{3}$ jenuh $1 \mathrm{ml} \mathrm{HCl} 1 \%, \mathrm{H}_{3} \mathrm{BO}_{3} 1 \%$, buffer $\mathrm{pH} 4$ dan $\mathrm{pH} 7$ serta akuades. Peralatan yang digunakan yaitu cool box, gelas ukur, gelas piala, pipet ukur, pipet tetes, mortar, cawan Conway, statif, mikroburet, inkubator, $\mathrm{pH}$ meter, kertas whatman, corong kaca, spatula, kertas label, timbangan analitik, pisau, tissue dan seperangkat peralatan untuk pengujian organoleptik, pulpen, score Penelitian ini bersifat eksploratif, dimana data diolah secara deskriptif menggunakan Microsoft excel pada rerata tiga variable independen dengan standar deviasi (SD).

Perlakuan dalam penelitian ini adalah sebagai berikut :

A: Waktu pengambilan sampel yang terdiri atas.

$$
\begin{aligned}
& \mathrm{A}_{1}=\text { Jam 06.00-07.00. } \\
& \mathrm{A}_{2}=\text { Jam 12.00-13.00. } \\
& \mathrm{A}_{3}=\text { Jam 17.00-18.00. }
\end{aligned}
$$

B: Pedagang yang terdiri atas

$$
\begin{aligned}
& \mathrm{B}_{1}=\text { Pedagang } 1 . \\
& \mathrm{B}_{2}=\text { Pedagang } 2 . \\
& \mathrm{B}_{3}=\text { Pedagang } 3 .
\end{aligned}
$$

Ulangan dalam penelitian ini adalah 3 kali pengambilan sampel yaitu hari pertama, hari kedua dan hari ketiga.

Parameter yang diamati adalah TVB-N, $\mathrm{pH}$ dan organoleptik (mata, insang, lendir permukaan bahan, daging dan tekstur). Hasil analisis diamati dengan rumus sebagai berikut: TVB-N (mg N/100 gr daging sampel) =

(a-b) $\times 0,28 \times$ pengenceran

$$
\begin{aligned}
& \text { Ket : } \\
& \mathrm{a}=\text { Jumlah } \mathrm{ml} \text { asam klorida yang dipakai }
\end{aligned}
$$

\section{HASIL DAN PEMBAHASAN}

Data hasil uji TVB-N ikan Tongkol segar pada waktu pengambilan sampel dan pedagang yang berbeda dapat nilai rerata uji TVB-N dapat dilihat pada Gambar 1.

Nilai rata-rata TVB-N ikan Tongkol yang terendah adalah $11,2 \mathrm{mg} \mathrm{N} / 100$ gr sampel pada pengambilan jam 06.00-07.00 sedangkan nilai rata TVB-N yang tertinggi yaitu $14 \mathrm{mg}$ -
$\mathrm{N} / 100 \mathrm{~g}$ sampel. Nilai rata-rata terendah pada pengambilan pada jam 12.00-13.00 adalah 11,2 $\mathrm{mg} \mathrm{N} / 100$ gr sampel sedangkan nilai rata-rata TVB-N yang tertinggi adalah $14 \mathrm{mg}-\mathrm{N} / 100 \mathrm{~g}$ sampel. Nilai rata-rata TVB-N yang terendah pada jam 16.00-17.00, 22,4 mg N/100 gr sampel sedangkan nilai rata-rata yang tertinggi adalah $28 \mathrm{mg} \mathrm{N} / 100$ gr sampel. Dengan melihat data TVB-N yang ada dapat dinyatakan bahwa ikan sampel pada pengambilan jam 06.0007.00, 12.00-13.00 dan 16.00-17.00 pada ketiga kelompok pedagang masih layak dikonsumsi.

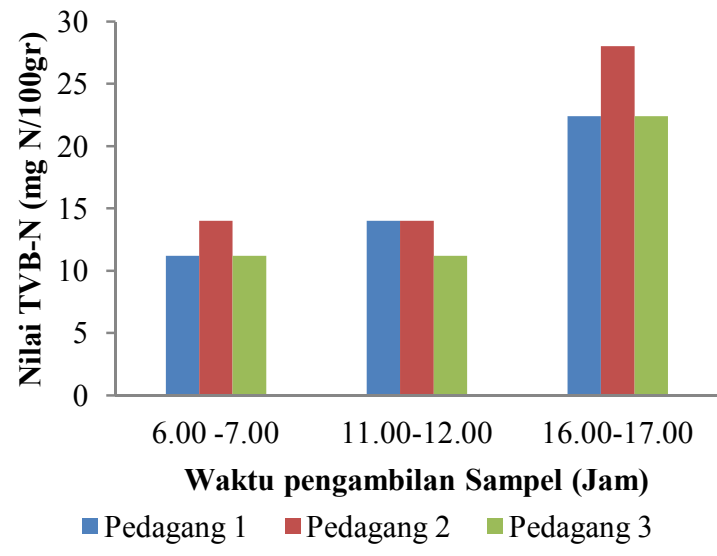

Gambar 1. Histogram hubungan waktu pengambilan sampel dan pedagang yang berbeda dengan nilai TVB-N ikan Tongkol segar.

Berdasarkan data yang diperoleh nilai TVB-N meningkat dari pagi hari sampai sore 06.00-07.00, 12.00-13.00 dan 16.00-17.00. Suwetja (1992), menyatakan bahwa nilai TVB$\mathrm{N}$ meningkat seiring dengan peningkatan aktivitas bakteri. Autolisis tidak dapat dihentikan walaupun dalam suhu yang sangat rendah. Penggunaan suhu rendah hanya memperlambat proses autolisis (Junianto, 2003). Data rata-rata nilai TVB-N untuk interaksi waktu pengambilan sampel dan pedagang masih berada dibawah $30 \mathrm{mg}-\mathrm{N} / 100 \mathrm{~g}$ sampel. Hal ini berarti ikan tersebut masih aman untuk dikonsumsi. Menurut Connel (1990) dalam Pongoh (2001), batas kandungan TVB ikan yang masih dapat diterima oleh konsumen adalah sebesar $30 \mathrm{mg}$ N/100 g sampel. Data hasil uji nilai TVB-N ini sesuai dengan hasil uji nilai $\mathrm{pH}$, yaitu untuk semua interaksi perlakuan nilai $\mathrm{pH}$ berkisar 5,$43 ; 5,4$; 5,$53 ; 5,46$ dan 5,56 dimana nilai $\mathrm{pH}$ ini 
menunjukkan ikan Tongkol yang diambil di Pasar Bahu masih dikaterogikan ikan segar.

Data di atas menunjukkan bahwa pengambilan sampel jam 06.00-07.00, 11.0012.00 dan $16.00-17.00$ mendapatkan nilai yang cukup lebih rendah dari $30 \mathrm{mg} \mathrm{N} / 100 \mathrm{~g}$ sampel ini berarti ikan Tongkol masih layak dikonsumsi. Pengukuran $\mathrm{pH}$ adalah prosedur yang digunakan dalam uji biokimia, karena menentukan banyak peranan penting dari aktivitas enzim (Suwetja, 1992). Nilai rataratahasil uji $\mathrm{pH}$ untuk sampel ikan Tongkol pada waktu pengambilan sampel yang berbeda 06.00-07.00, 11.00-12.00, 16.00-17.00 dan pedagang yang berbeda (pedagang 1, 2 dan 3) dapat dilihat pada histogram Gambar 3 berikut ini.

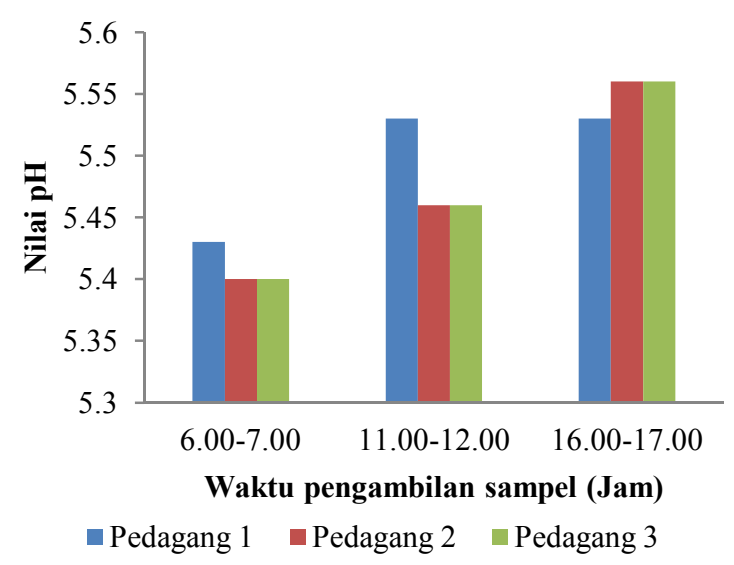

Gambar 2. Histogram hubungan waktu pengambilan sampel dan pedagang yang berbeda dengan nilai $\mathrm{pH}$ ikan Tongkol segar.

Nilai rata-rata $\mathrm{pH}$ ikan Tongkol sampel pada jam 06.00-07.00 nilai rata-rata terendah pada pedagang 2 dan 3 nilainya sama 5,4 sedangkan nilai tertinggi ditemukan pada pedagang 1 adalah 5,43. Nilai rata-rata $\mathrm{pH}$ terendah pada pengambilan jam 11.00-12.00 ditemukan pada pedagang 2 dan 3 nilainya sama 5,46 sedangkan nilai tertinggi ditemukan pada pedagang 1 adalah 5,53. Nilai rata-rata $\mathrm{pH}$ terendah pada pengambilan jam 16.00-17.00 ditemukan pada pedagang 1 adalah 5,53 sedangkan nilai tertinggi ditemukan pada pedagang 2 dan 3 nilainya sama 5,56. Dengan melihat data $\mathrm{pH}$ yang ada dapat disimpulkan bahwa ikan sampel pada pengambilan jam 06.00-07.00, 11.00-12.00, dan 16.00-17.00 pada ketiga kelompok masih layak untuk dikonsumsi.
pH adalah salah satu parameter untuk menentukan kemunduran mutu ikan dengan cara mengukur banyaknya ion $\mathrm{H}^{+}$dalam contoh inteperaksi $\mathrm{pH}<7,6$ menunjukkan mutu ikan segar, pH 7,6-7,9 menunjukkan dapat dimakan tapi bukan mutu nomor satu, dan $\mathrm{pH}>7,9$ menunjukkan nilai busuk (Sasmito, 2006). Berdasarkan hasil penentuan $\mathrm{pH}$, dapat dilihat bahwa setelah ikan mati terjadi penurunan $\mathrm{pH}$. Penurunan $\mathrm{pH}$ setelah ikan mati menambah aktivitas dari beberapa enzim dalam pemecahan protein. Kegiatan enzim aktif adalah setelah ikan mati yang menyebabkan $\mathrm{pH}$ daging menurun (Suwetja, 1992). Naiknya pH terutama diakibatkan oleh terbentuknya amoniak, kenaikan kadar tyrosin dan trymethylamin, serta dipengaruhi oleh terbentuknya asam-asam amino basa yang disebabkan oleh terjadinya perombakan sel jaringan ikan (Suwetja, 2004).

Uji organoleptik adalah cara penelitian dengan mempergunakan indera manusia (sensorik). Penilaian organoleptik merupakan cara yang paling cepat dilakukan dalam menentukan tanda-tanda kesegaran ikan karena lebih mudah dan lebih cepat dikerjakan, dan tidak memerlukan banyak peralatan (Hadiwiyoto, 1993). Penetapan kemunduran mutu ikan secara subjektif (organoleptik) dapat dilakukan dengan menggunakan score sheet yang telah ditetapkan oleh Badan Standardisasi Nasional (SNI-2346-2006), keadaan mata, daging perut, warna insang, lendir permukaan badan, bau dan tekstur. Tingkat penerimaan sampel diambil nilai tengah yaitu 5 , sebab nilai 5 merupakan nilai antara diterima dan tidak diterima ikan Tongkol. Nilai tengah ini dibulatkan untuk pengujian organoleptik terhadap mata, insang, daging, bau dan tekstur.

Mata merupakan salah satu bagian dari tubuh ikan yang dapat dijadikan parameter tingkat kesegaran ikan. Ikan segar memiliki ciri-ciri pupil hitam menonjol, kornea jernih, bola mata cembung dan cemerlang atau cerah (Afrianto dan Liviawaty, 1989). Bola mata ikan busuk memiliki ciri-ciri tampak suram, tenggelam dan berkerut (Adawyah, 2007). Berdasarkan hasil penelitian, diperoleh nilai organoleptik mata ikan Tongkol pengambilan sampel 06.00-07.00, 11.00-12.00, 16.00-17.00 dan pedagang yang berbeda (pedagang 1, 2 dan 3). Untuk histogram dilihat nilai rata-ratanya dilihat pada Gambar 3 berikut ini.

Data pada Gambar 3 ini menunjukkan bahwa pengambilan ikan Tongkol dijual oleh 
pedagang 1,2 dan 3 mempunyai nilai organoleptik mata yang tertinggi pada waktu pengambilan sampel pagi hari yaitu 9,4;9,76 dan 9,46 yang termasuk kategori ikan segar dan berturut-turut menurun pada waktu pengambilan sampel siang hari yaitu 8,$8 ; 8,7$ dan 8,73 juga termasuk kategori ikan segar dan sore hari yaitu 7,3; 7,76 dan 7,76 yang termasuk kategori ikan masih segar. Menurut BSN (2006), berdasarkan tingkat kesegaran maka nilai organoleptik ikan dikelompokkan kedalam 3 nilai yaitu ikan segar mempunyai nilai organoleptik 7-9, ikan agak segar mempunyai nilai organoleptik 5-6 dan ikan yang tergolong tidak segar mempunyai nilai organoleptik 1-3.

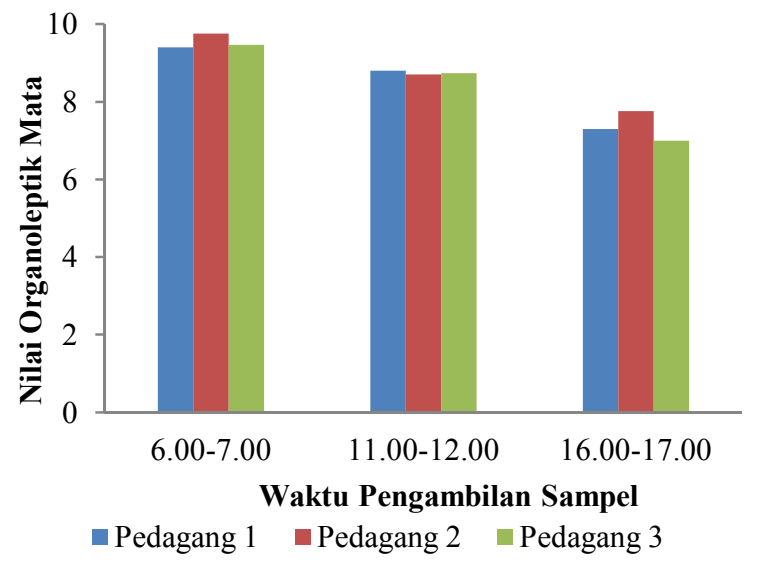

Gambar 3. Histogram hubungan waktu pengambilan sampel dan pedagang yang berbeda dengan nilai organoleptik mata ikan Tongkol segar.

Nilai organoleptik seperti ini kemungkinan disebabkan karena sampel yang diambil pada pagi hari adalah sampel segar yang baru dibeli dari tempat pelelangan ikan, sisa ikan yang tidak terjual pada pagi hari disimpan dalam cool box dan dijual lagi pada siang hari, hal yang sama dilakukan juga untuk penjualan sore hari, hal ini menyebabkan mutu ikan menurun dari waktu penjualan pagi hari ke siang hari dan selanjutnya ke sore hari. Data pada Gambar 3 di atas juga menunjukkan bahwa pengambilan sampel jam 06.00-07.00, 11.00-12.00 dan 16.00-17.00 mendapatkan nilai di atas angka 6 diambil sebagai nilai ambang batas dugaan untuk uji organoleptik ikan segar.

Insang merupakan bagian dari tubuh ikan yang banyak ditemukan adanya bakteri sehingga dapat dijadikan parameter kesegaran (Irawan, 1995). Insang yang segar berwarna merah cemerlang dan sedikit atau tidak ada lender (Yunizal dan Wibowo, 1998). Berdasarkan hasil penelitian, diperoleh nilai organoleptik insang ikan Tongkol dengan waktu pengambilan sampel yang berbeda yaitu jam 06.00-07.00, 12.00-13.00 dan 16.00-17.00 serta pedagang yang berbeda yaitu pedagang 1 , 2 dan 3 dapat dilihat pada Gambar 4.

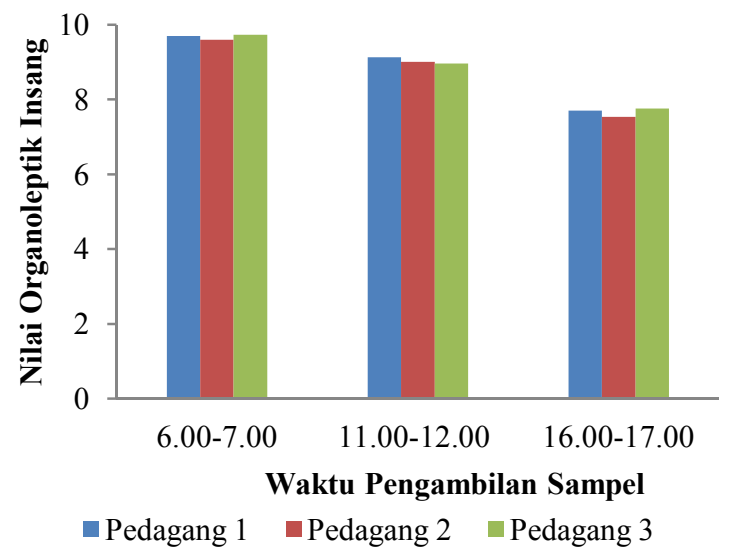

Gambar 4. Histogram hubungan waktu pengambilan sampel dan pedagang yang berbeda dengan nilai organoleptik insang ikan Tongkol segar.

Nilai organoleptik insang ikan Tongkol pada Gambar 4 menunjukkan bahwa baik pedagang 1,2 maupun 3 mempunyai nilai tertinggi pada waktu pengambiln sampel pagi hari yaitu 9,7;9,6;9,73 diikuti oleh waktu pengambilan sampel siang hari yaitu 9,$13 ; 9,0$; 8,96 dan sore hari 7,7; 7,53; dan 7,76 . Data ini mempunyai korelasi positif dengan data organoleptik mata dan lendir permukaan badan. Data ini menunjukkan bahwa ikan Tongkol yang dijual pada pagi hari adalah ikan Tongkol yang baru dibeli dari tempat pelelangan ikan yang mempunyai mutu segar, sedangkan ikan yang Tongkol dijual pada siang hari dan sore hari adalah ikan yang tidak laku terjual, selanjutnya disimpan dalam cool box dan dijual kembali pada siang hari dan demikian juga diperlakukan untuk ikan Tongkol yang dijual pada sore hari. Data di atas menunjukkan bahwa pengambilan sampel jam 06.00-07.00, 11.00-12.00, dan 16.00-17.00 mendapatkan nilai di atas angka 6 . Ini berarti dari nilai organoleptik insang, ikan sampel masih layak dikonsumsi.

Lendir merupakan salah satu bagian dari tubuh ikan yang dapat dijadikan parameter tingkat kesegaran ikan. Ikan segar memiliki 
ciri-ciri lendir di permukaan jernih dan transparan baunya segar menurut jenisnya atau lendir ikan tidak segar memiliki ciri-ciri lendir tebal serta lengket, warnanya berubah seperti putih susu (Junianto, 2003). Berdasarkan hasil penelitian, Gambar 5 diperoleh nilai organoleptik lendir ikan Tongkol yang dipasarkan di pasar Bahu dengan waktu pengambilan sampel yang berbeda (06.00$07.00,12.00-13.00,16.00-17.00)$ dan pedagang yang berbeda (pedagang 1, 2 dan 3 ).

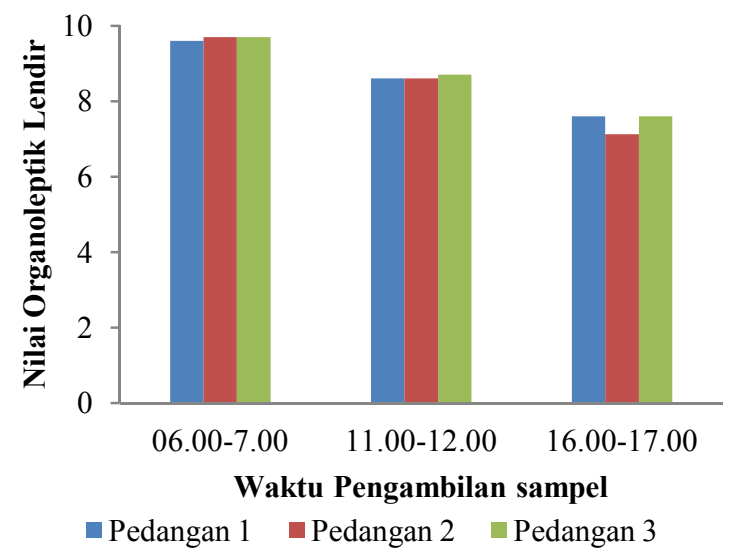

Gambar 5. Histogram hubungan waktu pengambilan sampel dan pedagang yang berbeda dengan nilai organoleptik lendir permukaan badan ikan Tongkol segar.

Nilai organoleptik lendir ikan Tongkol pada Gambar 5 menunjukkan bahwa baik pedagang 1, 2 maupun 3 mempunyai nilai tertinggi pada waktu pengambilan sampel pagi hari yaitu 9,6;9,7;9,7 diikuti oleh waktu pengambilan sampel siang hari yaitu 8,$6 ; 8,6$; 8,7 dan sore hari 7,$6 ; 7,13$; dan 7,6. Data ini mempunyai korelasi positif dengan data organoleptik mata dan lendir permukaan badan. Data di atas menunjukkan bahwa pengambilan sampel jam 06.00-07.00, 11.00-12.00 dan 16.00-17.00 mendapatkan nilai di atas angka 6 . Ini berarti dari nilai organoleptik lendir, ikan sampel masih layak dikonsumsi. Daging merupakan salah satu bagian dari tubuh ikan yang dapat dijadikan parameter tingkat kesegaran ikan. Ikan segar memiliki ciri-ciri daging cemerlang serta jika ikan dibelah daging melekat kuat pada tulang terutama rusuknya atau daging Ikan tidak segar memiliki ciri-ciri daging kurang cemerlang dan terdapat warna sepanjang tulang belakang serta jika dibelah daging mulai lepas.
Berdasarkan hasil penelitian, dilihat pada Gambar 6 memperlihatkan bahwa baik pedagang 1, 2 maupun 3 pada pengambilan sampel yang berbeda $(06.00-07.00 ; 11.00$ $12.00 ; 16.00-17.00)$ mempunyai data organoleptik daging (warna dan kenampakan) tertinggi terdapat pada waktu pengambilan sampel di pagi hari, selanjutnya nilai tersebut menurun untuk waktu pengambilan sampel siang hari dan sore hari. Hal ini menunjukkan bahwa ikan Tongkol segar yang dijual di pasar Bahu pada pagi hari adalah ikan yang baru tiba dari tempat pelelangan ikan, selanjutnya sisa ikan yang tidak habis terjual dipagi hari ini disimpan didalam cool box dan dijual kembali disiang hari, demikian pula untuk ikan yang dijual di sore hari.

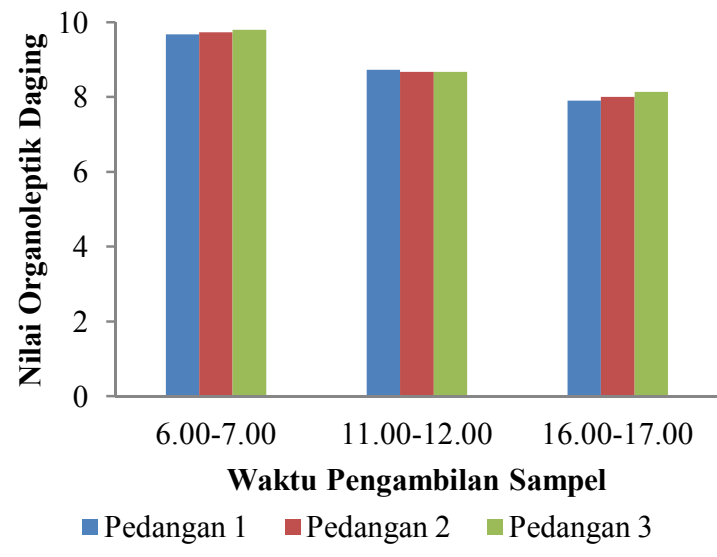

Gambar 6. Histogram hubungan waktu pengambilan sampel dan pedagang yang berbeda dengan nilai organoleptik daging ikan Tongkol segar.

Nilai organoleptik daging (warna dan kenampakan) memperlihatkan bahwa ikan sunglir yang diambil dipagi hari mempunyai nilai 9,$67 ; 9,73 ; 9,8$ ini artinya sayatan daging cemerlang, tidak ada pemerahan sepanjang tulang belakang dan dinding perut utuh. Ikan Tongkol yang diambil pada siang hari mempunyai nilai 8,$73 ; 8,67 ; 8,67$ ini menunjukkan ikan Tongkol tersebut kesegarannya sudah mulai menurun, ini artinya sayatan daging sedikit kurang cemerlang, tidak ada pemerahan sepanjang tulang belakang dan dinding perut daging utuh. Ikan Tongkol yang diambil sore hari sudah mempunyai nilai yang semakin menurun yaitu 7,$9 ; 8,0 ; 8,13$. BSN (2006), menyatakan bahwa nilai 7-9 masuk kategori ikan segar, sedangkan nilai 5-6 masuk kategori ikan agak segar. 
Tekstur merupakan salah satu bagian dari tubuh ikan yang dapat dijadikan parameter tingkat kesegaran ikan. Ikan segar memiliki ciri-ciri tekstur elastis dan jika ditekan tidak ada bekas jari serta padat atau kompak, ikan tidak segar memiliki ciri-ciri tekstur daging tidak elastis lunak dan jika ditekan dengan jari maka bekas tekanannya lama hilang, (Junianto, 2003). Nilai rata-rata hasil uji organoleptik daging ikan Tongkol segar pada waktu pengambilan sampel dan pedagang yang berbeda dapat dilihat pada histogram Gambar 7 berikut ini.

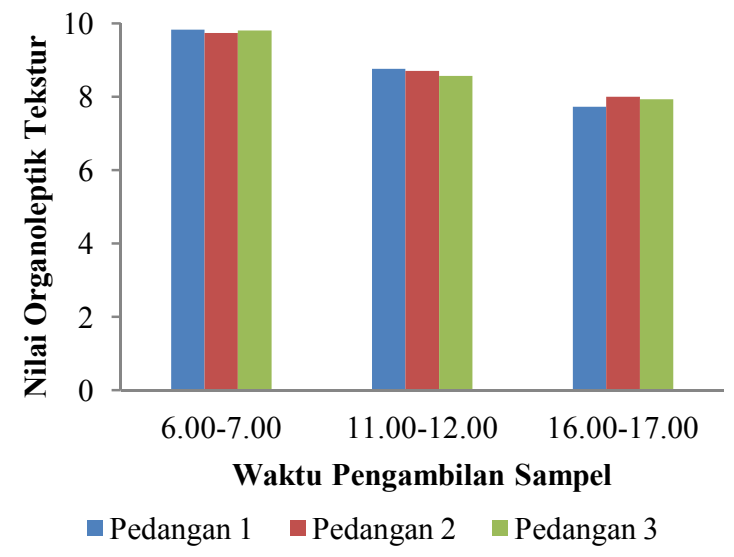
Gambar 7. Histogram hubungan waktu pengambilan sampel dan pedagang yang berbeda dengan nilai organoleptik tekstur ikan Tongkol segar.

Gambar 7 memperlihatkan bahwa nilai organoleptik tekstur ikan Tongkol yang dijual oleh ketiga pedagang di pasar Bahu pada pagi hari mempunyai nilai tertinggi yaitu 9,$83 ; 9,73$; 9,8. Nilai ini mempunyai arti tekstur agak padat, elastis bila ditekan dengan jari, sulit menyobek daging dari tulang belakang. Nilai organoleptik tekstur ikan Tongkol yang dijual pada siang hari mempunyai nilai 8,$76 ; 8,7 ; 8,5$, ini artinya tekstur agak lunak, berkas jari terlihat bila ditekan dengan jari, dan sulit menyobek daging dari tulang belakang. Nilai tektur pada tiga pedagang yang diambil pada sore hari mempunyai nilai tekstur yang semakin menurun yaitu 7,$73 ; 8,0 ; 7,93$.

Hasil penelitian menunjukkan bahwa untuk semua nilai organoleptik yaitu mata, insang, lendir permukaan badan, daging (warna dan kenampakan), dan tekstur terdapat korelasi positif yaitu nilai tertinggi pada ketiga pedagang terdapat pada pengambilan sampel pagi hari, selanjutnya menurun pada pengambilan sampel siang hari dan sore hari, walaupun demikian hasil uji organoleptik ini masih masuk kategori ikan bermutu segar dan agak segar. BSN (2006), menyatakan bahwa nilai ikan segar yang mempunyai nilai organoleptik 7-9 termasuk kategori ikan segar, sedangkan nilai 5-6 termasuk kategori ikan agak segar.

\section{KESIMPULAN}

Nilai rata-rata TVB $-\mathrm{N}$, ikan Tongkol (Euthynnus affinis) segar di pasar Bahu masih layak dikonsumsi sampai pada pengambilan sampel jam 16.00-17.00 dari ketiga pedagang, karena nilai batas kesegaran masih dibawah batas yaitu 11,2-22,4. Berdasarkan nilai $\mathrm{pH}$, Ikan Tongkol ini masih layak dikonsumsi sampai pada pengambilan sampel 16.00-17.00 dari ketiga pedagang, karena hal ini ditunjang oleh nilai $\mathrm{pH}$ yang masih di bawah batas kesegaran yaitu 5,4-5,56. Ikan Tongkol segar di pasar Bahu masih layak dikonsumsi sampai pada pengambilan sampel 16.00-17.00 dari ketiga pedagang. Hal ini ditunjang oleh nilai organoleptik yang masih baik.

\section{DAFTAR PUSTAKA}

Adawyah, Rabiatul. 2007. Pengolahan dan Pengawetan Ikan. Jakarta. PT Bumi Aksara.

Afrianto E, dan Liviawaty. 1989. Pengawetan dan Pengolahan Ikan. Penerbit Kanisius. Yogyakarta.

(BSN) Badan Standar Nasional. 2006. Standar Nasional Indonesia 01-2346. Uji Organoleptik Ikan Segar. Jakarta ; Badan Standarisasi Nasional Indonesia.

Hadiwiyoto, S. 1993. Teknologi Pengolahan Hasil Perikanan. Jilld 1. Penerbit Liberty. Jogyakarta.

Irawan, A. 1995.Pengolahan Hasil Perikanan Home Industri, Usaha Perikanan dan Mengkomersilkan Hasil Sampingan. Cv. Aneka. Solo

Junianto, 2003. Teknik Penanganan Ikan. Penebar Swadaya. Jakarta.

Soekarto, S. 1990. Penilaian Organoleptik Untuk Industri Pangan dan Hasil Pertanian. Jakarta. PT. Bumi Aksara.

Suwetja, I. K. 1992. Metode Penentuan Mutu Ikan. Penentuan Kesegaran Jilid I. Fakultas Perikanan Universitas . Manado.

2004. Konsep Biokimia Hasil Perikanan. Jilid III. Fakultas Perikanan dan llmu Kelautan. Universitas Sam Rarulangi. Mando.

Suwetja; I. K. J. Pongoh, M. Dalomam; 2006, Penentuan Rigor Indeks, $\mathrm{pH}$ dan Uji TVB-N Beberapa Jenis Ikan Laut. Manado; Paper; Fakultas Perikanan dan Ilmu Kelautan Universitas Sam Ratulangi. 
Suwetja, I. K., J. Pongoh, O. Jumriah. 2007. Penentuan Rigor Mortis, TMAO dan ATP; Diklat; Universitas Sam Ratulangi.
Yunizal, Wibowo S. 1998. Penanganan Ikan Segar. Jakarta. Instalasi Penelitian Perikanan Laut Sipil. 